\title{
CLONAL PROPAGATION OF TRICHOCENTRUM STRAMINEUM (ORCHIDACEAE), A THREATENED SPECIES ENDEMIC TO MEXICO
}

\section{PROPAGACIÓN CLONAL DE TRICHOCENTRUM STRAMINEUM (ORCHIDACEAE), UNA ESPECIE AMENAZADA ENDÉMICA DE MÉXICO}

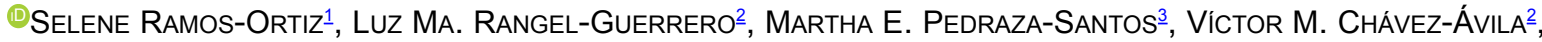

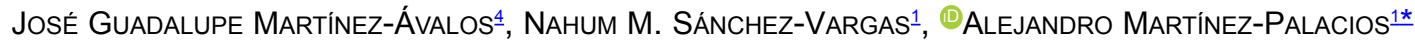

\author{
${ }^{1}$ Instituto de Investigaciones Agropecuarias y Forestales, Universidad Michoacana de San Nicolás de Hidalgo, Michoacán, \\ México. \\ 2Jardín Botánico, Instituto de Biología, Universidad Nacional Autónoma de México, México. \\ ${ }^{3}$ Facultad de Agrobiología "Presidente Juárez", Universidad Michoacana de San Nicolás de Hidalgo, Michoacán, México. \\ ${ }^{4}$ Universidad Autónoma de Tamaulipas, Instituto de Ecología Aplicada. Cd. Victoria, Tamaulipas, México.
}

*Corresponding author: apalacios56@gmail.com

\begin{abstract}
Background: Cloning techniques are applied to an endangered orchid species in order to reproduce individual plants and to preserve their genetic characteristics.

Objectives: To establish a new protocol for clonal propagation of a threatened orchid of horticultural importance.

Study species: Trichocentrum stramineum, a threatened orchid endemic to Mexico.

Study site and duration: Totutla, Veracruz, Mexico. All experiments were designed and carried out at the Botanical Garden-UNAM and the IIAF-UMSNH over a course of six years.

Methods: Seeds were germinated in a modified $\mathrm{KC}$ basal medium; protocorms and apical bud explants were obtained from the resulting in vitro plants and cultivated with or without plant growth regulators (PGRs). Both experimental groups were subcultured in order to evaluate the number of protocorm-like bodies (PLBs) and buds per explant.

Results: On average, protocorms generated 51.2 and 54.1 PLBs in the absence or presence of $1 \mathrm{mg} \mathrm{l}^{-1}$ 6-benzyladenine (BA), respectively, while 13.1 and up to 23.7 PLBs and / or shoots were observed on the apical bud explants in the absence or presence of 1 mg $1^{-1}$ kinetin, respectively. In both cases, responses were direct, without the formation of an intervening callus. Approximately 200 PLBs were subcultured and developed into whole plants within 14 weeks. These were acclimatized to greenhouse conditions with a $90 \%$ survival rate after 12 weeks. After 44 weeks, flowering was observed (3\%) individuals measuring at least $12 \mathrm{~cm}$ in height.

Conclusions: The developed protocol proved to hold great potential for commercial propagation and conservation programs.
\end{abstract}

Keywords: Apical bud, Flowering, PLB, Protocorm.

\section{Resumen}

Antecedentes: Las técnicas de clonación se utilizan para reproducir orquídeas en peligro de extinción, manteniendo las características genéticas de cada individuo a conservar.

Objetivos: Establecer un nuevo protocolo para la propagación clonal de una planta con importancia hortícola.

Especie de estudio: Trichocentrum stramineum, orquídea endémica y amenazada de México

Sitio y años de estudio: Totutla, Veracruz. El estudio duró 6 años, desarrollado en el Jardín Botánico UNAM y el IIAF, UMSNH.

Métodos: Las semillas germinaron en un medio basal $\mathrm{KC}$ modificado; se tomaron los protocormos y explantes de yemas apicales de las plantas in vitro resultantes y se cultivaron con o sin reguladores del crecimiento vegetal (PGR). Ambos se subcultivaron, evaluando el número de cuerpos similares a protocormos (PLB) y brotes unidos a cada explante.

Resultados: Los protocormos generaron en promedio 51.2 y 54.1 PLB en ausencia o presencia de $1 \mathrm{mg} \mathrm{l}^{-1}$ benciladenina respectivamente, mientras que se observaron 13.1 y hasta 23.7 PLB y / o brotes en los explantes de yema apical en ausencia o presencia de $1 \mathrm{mg} \mathrm{l}^{-1}$ de cinetina, en ese orden, ambas respuestas fueron directas sin presencia de callo. Aproximadamente 200 PLBs fueron subcultivados y desarrollados en plantas enteras en 14 semanas. Estas se aclimataron a condiciones de invernadero con una tasa de supervivencia del $90 \%$ después de 12 semanas. Después de 44 semanas, se observó floración (3\%) individuos que medían al menos $12 \mathrm{~cm}$ de altura.

Conclusiones: El protocolo desarrollado demuestra su potencial en programas comerciales de propagación y conservación.

Palabras clave: Floración, PLB, Protocormo, Yema apical. 
With 23,314 species, almost half of them being endemic, Mexico ranks fourth in biodiversity of vascular plants by country (Villaseñor 2016). The Orchidaceae family is one of the four best represented families in the country and comprehends 1,254 reported species, $35 \%$ of which are endemic (Soto-Arenas et al. 2007a, b). Unfortunately, most of them are at risk of extinction due to land use change and collecting of wild plants, a fact that is even more alarming in the case of species with restricted distribution and low population density. Trichocentrum stramineum (Lindl.) Chase \& Williams, syn Lophiaris straminea: Oreja de burro (donkey ear), is a threatened endemic species (SEMARNAT 2010, Remolina 2015) and listed in Appendix II of the Convention on International Trade in Endangered Species of Wild Fauna and Flora (CITES 2017). Its distribution is limited to the tropical deciduous, oak, and pine-oak forests of the Mexican states of Veracruz and Puebla (Vovides et al. 1997, Espejo-Serna et al. 2005). The factors that put it at risk of extinction are the same that affect most orchids (Espejo-Serna et al. 2005); e.g., the introduction of exotic timber species has caused many problems in this regard (Valdiviezo \& Castillo 2011). Especially bamboos (Bambusa spp., Gradua spp. and Phyllostachis spp.) have shown to contribute significantly to the displacement of native species that occur in the distribution area of T. stramineum, due to the former's ability to spread rapidly and widely for a number of reasons: Bamboos can propagate themselves by asexual reproduction and, with their $\mathrm{C} 4$ carbon fixation pathway and dense stem growth, tend to be well-adapted to cloud forests. In some areas, the expansion of these species has gone out of control, invading the surrounding ravines at an ever higher rate. Although the plant is difficult to grow by traditional methods (Remolina 2015), T. stramineum is a species of horticultural interest (Espejo-Serna et al. 2005).

When cloning techniques are used to reproduce plants for commercial purposes, it is important that the selected genotype can be massively propagated in a short period of time without compromising the desired characteristics (George 1993, Arditti 2008). Cloning also occurs naturally in wild plants and is sometimes more efficient than sexual propagation, e.g., favorable genotypes that contribute descendants by both sexual and asexual reproduction may perpetuate their genes within a population for generations (Gentry 1982, Nobel 1985, 1992). In the case of populations facing imminent extinction, represented by a few unique genotypes only, repeated small scale clonal multiplication can be the last resort to avoid vanishing of the former (Mistretta 1994, Martínez-Palacios et al. 2016). An efficient cloning method distinguishes itself by simple and shortterm cultivation processes that promote direct morphogenic responses. It is also essential to keep plant growth regulator (PGR) concentrations low or not to add them at all to the culture media, in order to decrease the probability of irregular cell divisions or mutations (and thus genetic variation) during cultivation (George 1993, MartínezPalacios et al. 2003, 2016). Plant tissue culture (PTC) is a widely used technique for mass propagation and can make use of regeneration pathways that either maintain the genetic stability of crops or promote genetic instability (George 1993); e.g., the addition of PGRs can be avoided by cultivating plant tissues and organs in liquid media under continuous agitation (Mehrotra et al. 2007), which frequently results in the disruption of apical dominance and the subsequent induction and proliferation of numerous axillary buds. Furthermore, this technique provides appropriate levels of aeration and nutrients to the explants (Park et al. 2002, Mehrotra et al. 2007).

Genetic changes can occur in in vitro cultures at the cellular and / or molecular level, in the latter case including specific DNA mutations (Radić et al. 2005). Various factors, such as the genotype and age, as well as the culture and explant type, influence the incidence of somaclonal variation. Changes concerning chromosome number and structure are often related to ploidy levels (Evans 1989, Radić et al. 2005).

A crop's specific propensity for somaclonal variation can be indicated by the effects that different types and concentrations of PGRs have on the morphogenic response or dedifferentiation of the respective in vitro cultures, particularly when taking into account the number of subcultures necessary to induce these phenomena (Bairu et al. 2006, 2011, Vujović et al. 2010, Miguel \& Marum 2011). For instance, high concentrations of the cytokinin benzyl amino purine (BAP) have been reported to induce somaclonal variation in plant tissue cultures established from several species belonging to the genera Fragaria (Biswas et al. 2009), Musa (Bidabadi et al. 2010), and Saccharum (Singh et al. 2008).

Environmental stress, such as high temperatures, can cause in vitro grown plant cells to attack their own plastids with antibiotic-like compounds or to undergo chromosome doubling. Doubled haploidy, for instance, may result in the formation of albino plants in the case of several important cereal crops (Torp \& Andersen 2009).

Somaclonal variation can also be induced by subculturing PTCs over prolonged periods of time, as has been demonstrated previously in pineapple (Ananas comosus (L.) Merr; da Silva et al. 2016). In other species like chestnut rose (Rosa roxburghii Tratt), however, Random Amplification of Polymorphic DNA (RAPD) and Amplified Fragment Length Polymorphism (AFLP) analyses proved that in vitro propagated shoots are able to maintain genetic stability even after 25 subculture cycles (Wen \& Deng $\underline{2005}$ ). This suggests that subculturing on itself does not cause somaclonal variation, but may do so in combination 
with other factors, some of which have already been mentioned above.

In contrast, the use of explants obtained from apical meristems or immature plant tissues and organs facilitates the production of genetically stable regenerants (Williams \& Maheswaran 1986, Balachandran et al. 1990, George 1993, Rani \& Raina 2000, Martins et al. 2004), as the former are mainly composed of totipotential undifferentiated or meristematic cells, respectively (Williams \& Maheswaran 1986, George 1993). Clonal multiplication has been successfully applied to ginger sprouts (Hosoki \& Sagawa 1977, Balachandran et al. 1990, Rout et al. 2001), and RAPD, Simple Sequence Repetition (SSR), and / or Inter Simple Sequence Repetition (ISSR) analyses have shown the genetic stability of micropropagated poplar plants (Rani et al. 1995), somatic embryos of Psidium guajava L. (Rai et al. 2012) and different fir species (Isabel et al. 1996), as well as of Saccharum officinarum L. seedlings (Pandey et al. 2012) and Prunus dulcis (Mill.) DA Webb. shoots (Martins et al. 2004) produced by direct organogenesis or axillary branching, respectively.

The addition of organic extracts (coconut water and banana pulp, among others) to the culture medium favors the in vitro development of orchid plants (Ernst 1967, Morel 1974, Aktar et al. 2008). The use of activated charcoal can also have beneficial effects, because it retains toxic elements generated by tissue, organ, and whole plant cultures in a time-dependent manner (Morel 1974). With regard to the orchids, the development from seeds to flowering plants is a slow process that can take eight years of cultivation (Morel 1974). The phenological stages of this development have been described in the case of the in vitro asymbiotic germination of $T$. stramineum, and germination rates of up to $47.69 \%$ have been reported (Flores-Escobar et al. 2008). Methods for the in vitro culture of this species in organic media have also been published, but the adaptation of the micropropagated plants to soil conditions and their subsequent development has not been covered yet (Flores-Escobar et al. 2008). Therefore, the objective of the present work was to establish a protocol for the clonal propagation of $T$. stramineum, a threatened species endemic to Mexico, by inducing the formation of multiple PLBs on protocorms, and of PLBs and shoots on apical bud explants, respectively, as well as to describe the propagated plants' development under in vitro and greenhouse conditions.

\section{Materials and methods}

Biological material. Trichocentrum stramineum seeds were obtained from three mature fruits taken from different plants in a tropical deciduous forest near the Conejos-Huatusco highway, locality of Mata Oscura, Municipality of Totutla, Veracruz, Mexico. Voucher specimens were deposited at the
Herbarium of the Autonomous University of Tamaulipas (voucher number UAT MA2019). Apical buds were obtained from in vitro-grown plants.

Study design and conduction: All experiments were designed and carried out at the Botanical Garden-UNAM and the IIAF-UMSNH over a course of six years.

Culture medium. The basal medium was KC-E, a modified KC medium (Knudson 1946) enriched with micronutrients (in mg $\cdot 1^{-1}, 0.056$ of $\mathrm{H}_{3} \mathrm{BO}_{3}, 0.016$ of $\mathrm{MoO}_{3}, 0.040$ of $\mathrm{CuSO}_{4}$, 0.331 of $\mathrm{ZnSO}_{4} .7 \mathrm{H}_{2} \mathrm{O}, 0.083$ of $\mathrm{KI}, 0.0025$ of $\mathrm{CoCl}_{2} \cdot 6 \mathrm{H}_{2} \mathrm{O}$ ), vitamins of the B5 medium (Gamborg et al. 1968), 100 $\mathrm{mg} \cdot \mathrm{l}^{-1}$ of myo-inositol, $20 \mathrm{~g} \cdot \mathrm{l}^{-1}$ of sucrose, and $8 \mathrm{~g} \cdot \mathrm{l}^{-1}$ of agaragar (SIGMA A-1296). After adjusting the medium's $\mathrm{pH}$ to 5.0 , it was sterilized in an autoclave at a pressure of $1.5 \mathrm{~kg} \cdot \mathrm{cm}^{-2}$ for 15 minutes.

Asymbiotic seed germination. The seeds were disinfected in a solution of $7 \%$ calcium hypochlorite for $30 \mathrm{~min}$, and then rinsed thrice with sterile distilled water. Between 200 and 300 seeds were suspended in $0.5 \mathrm{ml}$ of sterile distilled water and dispersed on the surface of $15 \mathrm{ml}$ of solid KC-E medium in $100 \times 15 \mathrm{~mm}$ Petri dishes. The number of germinated seeds was recorded twenty days later with a stereo microscope ZEISS Stemi 200-C. Increase in size (measured with a vernier scale), green coloring, rupture of the seed coat, and initiation of the protocorm stage were all considered signs of germination. The experimental group consisted of six repetitions, and the corresponding germination rates were indicated as average values. Leftover disinfected seeds were sown in $250 \mathrm{ml}$ jars containing $40 \mathrm{ml}$ of basal medium in order to facilitate their germination. All cultures were incubated at $26 \pm 1{ }^{\circ} \mathrm{C}$ and exposed to a $16 \mathrm{~h}$ light $/ 8 \mathrm{~h}$ darkness photoperiod and at photosynthetic photon flux density (PPFD) of $60 \mu \mathrm{mol} \mathrm{m}{ }^{-2}$ $\mathrm{s}^{-1}$, during 30 days.

Cultivation of protocorm and apical bud explants in liquid medium under orbital agitation at $100 \mathrm{rpm}$. Thirty days after germinating, protocorms with a morphology characteristic of development stage 2 (diameter of $1 \mathrm{~mm}$; spherical shape; absent or incipient apical buds) were subcultivated in liquid KC-E medium, in the absence or presence of $1 \mathrm{mg} \cdot \mathrm{l}^{-1}$ of 6-benzyladenine (BA). In either case, approximately $0.5 \mathrm{~g}$ of protocorms were transferred to $250 \mathrm{ml}$ Erlenmeyer flasks containing $80 \mathrm{ml}$ of medium. The cultures were maintained for eight weeks under the following conditions: continuous orbital shaking at $100 \mathrm{rpm}$; temperature of $27 \pm 1{ }^{\circ} \mathrm{C}$; 16 light/ $8 \mathrm{~h}$ darkness photoperiod (PPFD $20 \mu \mathrm{mol} \mathrm{m} \mathrm{m}^{-2} \mathrm{~s}^{-1}$ ) provided by $40 \mathrm{~W}$ fluorescent white light tubes. 
Apical bud explants measuring between 1 and $3 \mathrm{~mm}$ in length were obtained from in vitro-grown plants, and cultivated in three different liquid KC-E media: One did not contain any PGRs, while the other two were enriched with 1 $\mathrm{mg} \cdot \mathrm{l}^{-1}$ of kinetin (Kin) or $2 \mathrm{mg} \cdot \mathrm{l}^{-1}$ of Kin and $1 \mathrm{mg} \cdot \mathrm{l}^{-1}$ of 2, 4-dichlorophenoxyacetic acid (2,4-D), respectively. Each repetition consisted of ten explants in $125 \mathrm{ml}$ Erlenmeyer flasks filled with $25 \mathrm{ml}$ of liquid medium and was maintained for 16 weeks under the conditions described for orbital shaking.

$P L B$ and shoot formation in solid medium. Some of the protocorms developed under agitation in liquid KC-E media with and without BA were randomly selected for subculturing in solid KC-E medium without PGRs. Each protocorm was placed in a $125 \mathrm{ml}$ jar containing $30 \mathrm{ml}$ of medium, and each treatment consisted of 12 repetitions. The cultures were maintained at $27 \pm 1{ }^{\circ} \mathrm{C}$ and a $16 \mathrm{~h}$ photoperiod (PPFD: $60 \mu \mathrm{mol} \mathrm{m}^{-2} \mathrm{~s}^{-1}$ ) for eight weeks.

Subculture of PLBs and shoots derived from protocorm and/or apical bud explants, and their in vitro development into whole plants. Protocorms, PLBs, and shoots originated from asymbiotic germination or from protocorm and apical bud explants under orbital agitation, respectively, were subcultured individually in jars $(13.2 \times 7.6 \mathrm{~cm})$ containing $80 \mathrm{ml}$ solid KC-E medium enriched with $20 \%$ coconut water and $1 \mathrm{~g} \cdot \mathrm{l}^{-1}$ of activated carbon, under the above mentioned conditions. Apical bud explants cultivated in liquid medium under orbital agitation were subcultured identically, with 20 repetitions per treatment. After 14 weeks, they had developed into whole plants with at least four leaves and three roots.

Acclimation of regenerated whole plants to greenhouse conditions. The whole plants originated from the protocorm-derived PLBs were extracted from the jars, washed under running water, and planted in circular trays (40 $\mathrm{cm}$ in diameter and $18 \mathrm{~cm}$ in height, with $10 \mathrm{~mm}$ perforations in the bottom to facilitate drainage) filled with a bottom layer of basalt rock ( 2 to $3 \mathrm{~cm}$ in diameter) and a top layer (4 $\mathrm{cm}$ in height) of moss substrate (Thuidium sp. and Hypnum sp.). The trays were watered between 2 and 3 times a day for 12 weeks, and then once a day for the remaining time. The propagation process of $T$. stramineum is described in Figure 1.

Statistical analysis. Statistical Analysis Software (SAS 1999) was used to evaluate the study results. Data was normalized with PROC STANDARD (z score; mean $=0$, std $=1)$. Significant differences between treatments were determined by Student's t-test $(P=0.95)$ in the case of the induction of PLB formation on protocorms cultivated in liquid medium with and without BA, and by ANOVA $\left(R^{2}=0.150026, P=<0.0001^{*}\right)$ in the case of the response of the apical buds.

\section{Results}

Seed germination. Notwithstanding that first indicators of asymbiotic seed germination were observed nine days after initiation of the cultures, the number of germinated seeds was only registered after 20 days. An average germination rate of $87.9 \%$ was determined in solid KC-E medium (pH 5).

Diameter increase of protocorms and shoot induction in stem apex explants exposed to liquid medium under constant orbital agitation. After eight weeks of cultivation in liquid medium under orbital agitation, the protocorms obtained by asymbiotic seed germination showed diameter increases between 3 and $9 \mathrm{~mm}$ (relative to the initial $1 \mathrm{~mm}$ ). Although the medium darkened over time, the protocorms presented a hard consistency, a light-yellow color, and a spherical shape (Figure 2B and C). Occasionally, either aborted shoots (Figure 2C above) or small protuberances (Figure 2C below) formed on the surface of the protocorms. The protuberances could develop into PLBs and originate new protocorms when separated from their respective explants.

While only a few apical bud explants developed PLBs, it was common to observe direct shoot formation on the axillary buds of the former during the 14 weeks of cultivation in liquid medium. Explants grown in basal KC-E medium produced an average of 13.1 shoots, whereas the addition of Kin resulted in a significantly higher number of shoots (up to 23.7 per explant; Table 1). When transferred to solid medium, the regenerated shoots continued to develop satisfactorily into whole plants.

PLB formation on protocorm explants and development of apical bud explant-derived shoots in solid medium. In all cases, direct PLB formation was observed on the surface of the protocorms. The number of PLBs per explant varied from 14 to 108, and similar average values were determined for protocorms previously cultivated in the absence or presence of BA (51.2 and 54.1 PLBs, respectively). The PLBs soon acquired an intense green color (Figure 2D) and could be separated from the protocorm explants with a spatula. Interestingly, it became evident that the PLBs had partly absorbed the tissue of the protocorm explants and that they were not connected with each other. They eventually developed into plantlets and shoots (Figure 2D-F). 


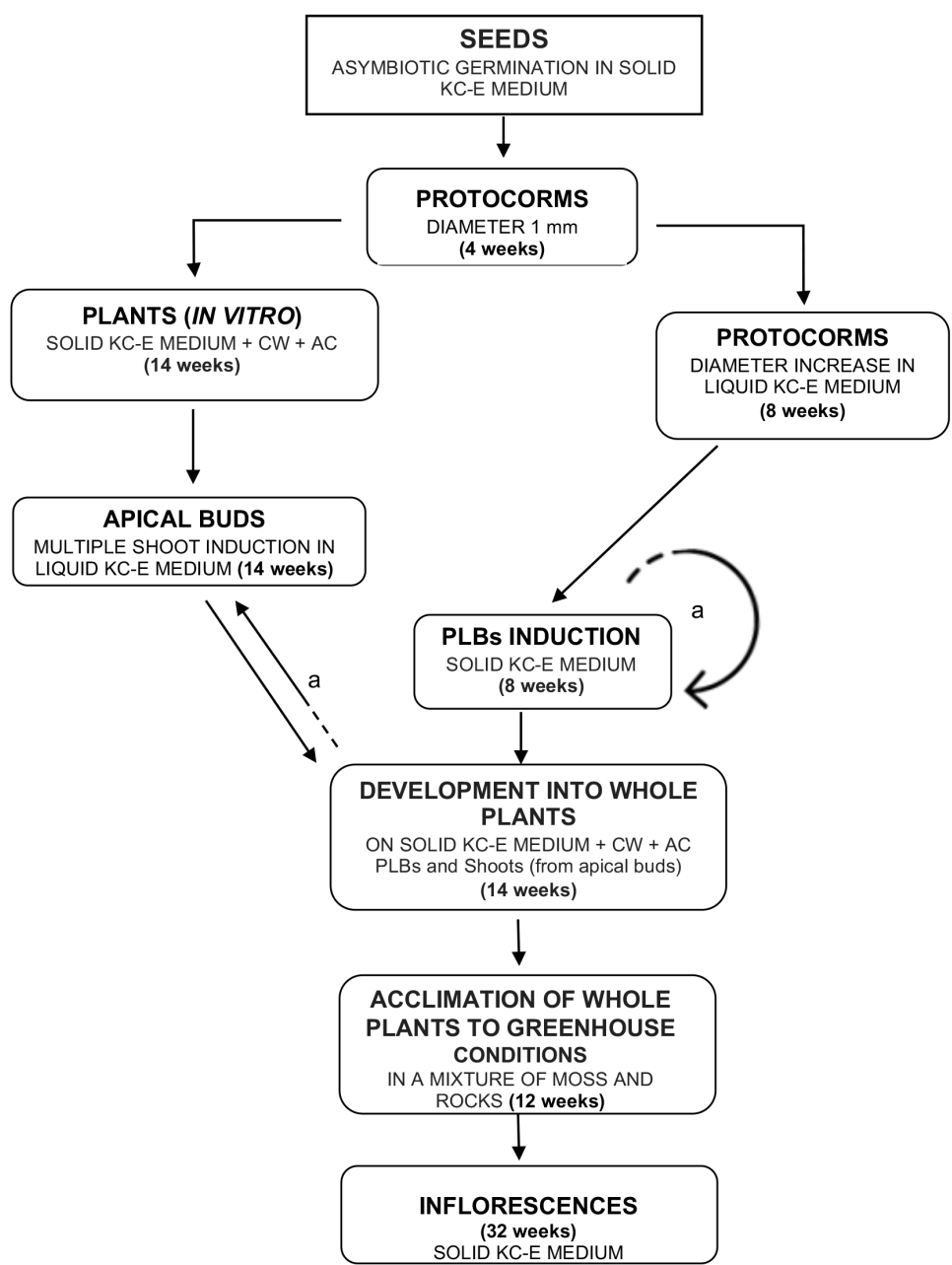

Figure 1. Workflow diagram for clonal propagation of Trichocentrum stramineum. ${ }^{\text {a }}$ : In vitro potential for mass propagation of horticultural interest. CW: $20 \%$ coconut water; AC: activated carbon $1 \mathrm{~g} \cdot \cdot^{-1}$; PGR: plant growth regulator.

Since the protocorm explants previously cultivated in BA-containing liquid medium did not show statistically significant differences $(P=0.7195)$ with reference to diameter increase and PLB formation in comparison to the control group, this PGR was not added to the solid basal KC-E medium.

In vitro development of protocorms, PLBs, and shoots into whole plants. The protocorms, as well as the regenerated PLBs and shoots originated whole plants following a normal development pattern, devoid of callus formation, hyperhydric symptoms, or further PLB generation. The roots and leaves of the in vitro whole plants did not present morphological abnormalities (Figure 2G). It should be noted that only the PGR-free experimental groups were monitored at this stage, and it can thus not be ruled out that the use of certain PGRs could induce somaclonal variation in any of the mentioned in vitro cultures and structures.
Acclimation of regenerated whole plants to greenhouse conditions. After 12 weeks of having been transplanted to non-sterile substrate under greenhouse conditions, $90 \%$ of the regenerated whole plants were still alive. Morphological abnormalities were not observed at all, and sizes ranged from 4 to $12 \mathrm{~cm}$ in height (Figure $2 \mathrm{H}$ ). The leaves were elliptic, thick, and reddish-green due to the presence of red pigments. They measured between 10 and $15 \mathrm{~cm}$ in length and between 2.7 and $3.5 \mathrm{~cm}$ in width. After 44 weeks in the greenhouse, $3 \%$ of the plants that had grown to a height of at least $12 \mathrm{~cm}$ under in vitro conditions, developed inflorescences of 12 to 15 flowers whose sizes (diameter of 12 to $15 \mathrm{~mm}$ ), shapes, and colors (off-white or ivorycolored sepals and petals with a yellow spot at the base; yellow red-spotted trilobed lips with a white middle part and red dots at its base) were similar to those characteristic of wild plants (Figure 2I). Flowering under greenhouse conditions in Mexico City took place in March. 


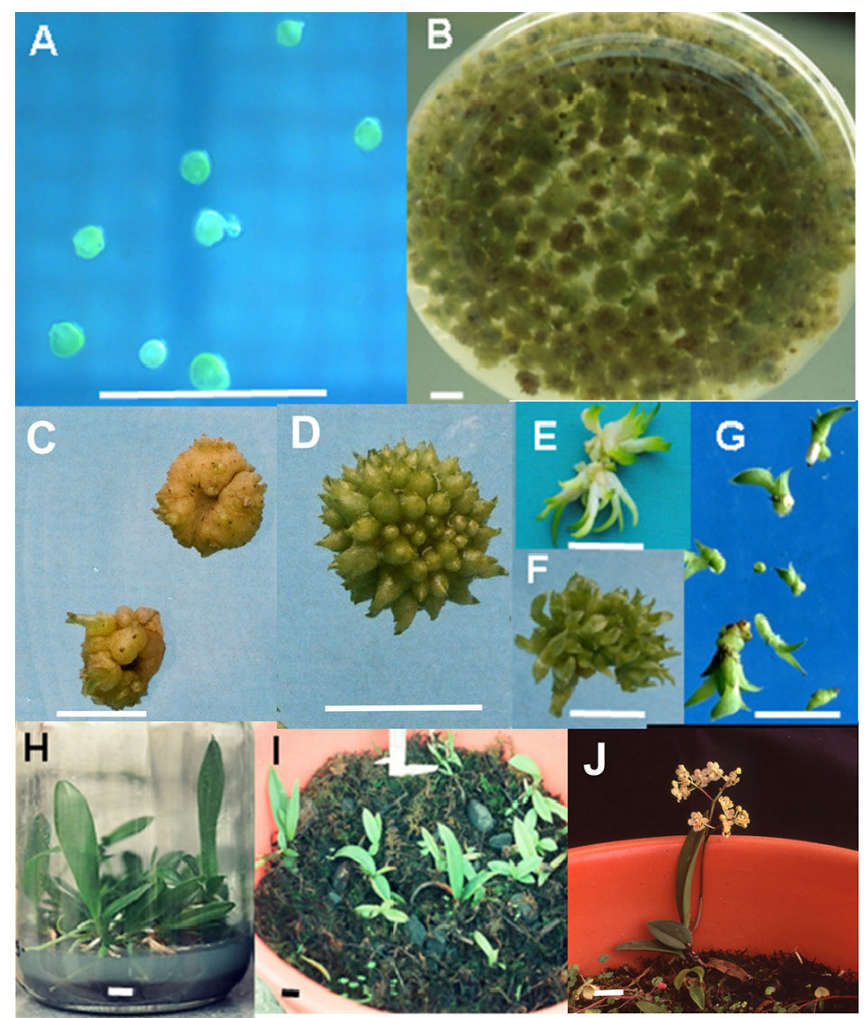

Figure 2. Clonal propagation of Trichocentrum stramineum in liquid culture medium under orbital agitation. A) Protocorms in development stage 2, 30 days after initiating the cultures; B) Protocorm explants after eight weeks in liquid medium under orbital agitation at 100 rpm; C) Protocorm with first signs of PLB formation, after eight weeks in liquid medium; D) PLBs formed on protocorm cultivated for eight weeks on solid medium; E) Regenerated shoots obtained from the apical bud explants cultivated in liquid medium; F) Regenerated shoots obtained from the protocorm explants cultivated on solid medium for eight weeks; G) PLBs and plantlets separated from their respective explants; H) in vitro whole plants derived from regenerated PLBs, after 12 weeks of cultivation on solid medium; I) Whole plants acclimated to greenhouse conditions, 32 weeks after initiating the in vitro cultures; J) Flowering plant after 44 weeks in the greenhouse. Scale bar $=10 \mathrm{~mm}$

\section{Discussion}

Seed germination. In this work, the asymbiotic germination rate of $T$. stramineum seeds exposed to solid KC-E medium proved to be significantly higher than the reported $47.69 \%$ of seeds that germinated on MS medium according to a previous study (Flores-Escobar et al. 2008). This difference may be due to the particular high concentrations of salts in the latter medium (Bell et al. 2009), which can exert inhibitory effects on seed germination (Rodríguez et al. 2014), alter in vitro development, or even induce tissue necrosis (George 1993, Cassells \& Curry 2001). With respect to the $\mathrm{pH}$ of the medium, the optimum values for germination of orchid seeds range from 4.8 to 5.2, with an extended interval of 3.6 to 7.6 (Arditti \& Ernst 1984).

The relatively low concentrations of mineral salts and inorganic nitrogen contained in $\mathrm{KC}(\mathrm{pH} 5.0)$ and $\mathrm{VW}$ media ( $\mathrm{pH}$ 5.2) promoted germination in species belonging to the Paphiopedilum genus, an effect not observed in the case of quarter- or half-strength MS medium (pH 5.8; Long et al. 2010). Johnson \& Kane (2007) also reported higher germination frequencies in Vanda hybrid seeds when exposed to $\mathrm{KC}$ medium. This stimulating effect on the germination of orchid species may be associated with the medium's higher calcium concentration $(4.23 \mathrm{mM})$ in comparison to the VW (1.94 mM) and MS media (quarterstrength: $0.75 \mathrm{mM}$; half-strength: $1.5 \mathrm{mM}$ ). Furthermore, in contrast to most other plant groups, many orchids grow on fairly acid soils.

Diameter increase of protocorms and shoot induction in stem apex explants exposed to liquid medium under constant orbital agitation. The protocorms increased considerably in diameter, reaching values of up to ten times their initial size. In this regard, it should be pointed out that diameter increases of plant tissues grown in liquid media under orbital agitation are often associated with the disruption of apical dominance (Mehrotra et al. 2007), and that the effective use of this technique is in agreement with other studies that have applied similar culture conditions to different types of explants and orchid species, such as leaf segments of Phalaenopsis spp. (Park et al. 2002) and nodal segments of Dendrobium candidum (Cui et al. 2015). 
Table 1. Effect of PGRs on shoot induction in T. stramineum apical bud explants cultivated in liquid media under orbital agitation.

\begin{tabular}{lcccc}
\hline Treatment & $\boldsymbol{n}$ & Shoots/explant (average) & Tukey & e.e. \\
\hline 0 (control) & 13 & 13.1 & $\mathrm{~b}$ & 2.0 \\
$1 \mathrm{mg} \cdot \mathrm{l}^{-1}(\mathrm{Kin})$ & 16 & 23.7 & $\mathrm{a}$ & 1.8 \\
$2-1 \mathrm{mg} \cdot \mathrm{l}^{-1}(\mathrm{Kin}-2,4-\mathrm{D})$ & 16 & 18.2 & $\mathrm{ab}$ & 1.8 \\
\hline
\end{tabular}

Kin: Kinetin; 2,4-D: 2,4-dichlorophenoxyacetic acid; $P=0.001$

As high concentrations of cytokinins like BA can interfere with cell division and may induce somaclonal variation in some species (Bairu et al. 2006), the effect that this PGR might have on the induction of PLBs in protocorm cultures was not evaluated. Interestingly, in in vitro cultures of Turbinicarpus valdezianus (Möeller) Glass \& R.A. Foster (Martínez-Palacios et al. 2016), the above mentioned side effects did occur when the same species was exposed to BA (Dávila-Figueroa et al. 2005). Whenever use of these compounds is essential for propagation purposes, their concentrations should therefore be kept as low as possible, and multiplication periods be reduced (Martínez-Palacios et al. 2003, 2016).

PLB formation on protocorm explants and development of apical bud explant-derived shoots in solid medium. In the case of orchids, direct shoot induction on stem apex explants has only been registered a few times (Rubluo et al. 1993, Martin \& Madassery 2006), the vast majority of publications concerning the in vitro regeneration of these plants reports the direct or indirect formation of PLBs ( $\underline{\text { Zhao }}$ et al. 2008, Khoddamzadeh et al. 2011, Niknejad et al. 2011). The direct induction of PLBs and shoots on protocorms and stem apex explants, respectively, implies morphogenetic responses that are among the most stable in PTC (George 1993, Rubluo et al. 1993, Martins et al. 2004, Bhattacharyya et al. 2014).

Furthermore, our results suggest that PLB formation was caused by disruption of apical dominance and subsequent diameter increase in the protocorm explants, both consequences of exposing the latter to orbital shaking in liquid medium. The low number of PLBs generated on apical buds may be due to the fact that the longest explants $(3 \mathrm{~mm})$ floated on the liquid medium without being able to rotate freely in all directions. In consequence, unlike the protocorm explants, they did not increase in diameter. However, the culture conditions allowed for the emergence of shoots from the axillary buds that are naturally present in stem apices.

In vitro development of protocorms, PLBs, and shoots into whole plants. In agreement with previous publications, the enrichment of the basal growth media with coconut water and activated carbon favored the in vitro development of the orchids, (Morel 1974, Martínez-Palacios 1991, Rubluo et al. 1993, Aktar et al. 2008). The fact that $20 \%$ of the regenerated $T$. stramineum whole plants reached at least $12 \mathrm{~cm}$ in height (Figure 2G) may be attributed in part to this factor.

Acclimation of regenerated whole plants to greenhouse conditions. Despite the fact that micropropagated plantlets tend to be fragile and may not be sufficiently vigorous to survive the acclimatization shock resulting from transplanting them from in vitro to soil substrates (Jeon et al. 2005), the survival rate of $T$. stramineum plantlets was high. The first days after transplanting are crucial, and conditions should mimic those of the original in vitro cultures, providing dim light and high relative humidity. The plantlets can then gradually be subjected to higher stress levels in order to harden them off and prepare them for normal plant development under greenhouse or outdoor conditions (Rubluo et al. 1993, Jeon et al. 2005, Cha-um et al. 2010).

Considerations on mass propagation for commercial use. The protocol described in this study showed great potential for the mass propagation of $T$. stramineum. Assuming regeneration rates of 51.2 PLBs per protocorm and 13.1 shoots per apical bud explant after 18 weeks of cultivation in PGR-free liquid medium under orbital agitation, one protocorm could originate 134,218 PLBs in a period of 54 weeks (three cycles). For comparison, species of Phalaenopsis can be propagated at a rate of 18,000 PLB per $20 \mathrm{~g}$ of inoculum (approximately 1000 PLB sections) using 2 liters of medium and a cultivation time of eight weeks (Park et al. 2002). The solid KC-E medium enriched with coconut water and activated carbon proved to be appropriate for the development of the regenerated PLBs, shoots, and eventually whole plants. Particularly the occurrence of flower formation in less than a year suggests that commercial scale-up of our protocol could lead to the development of farming systems for $T$. stramineum, similar to those already existing for other orchid species, such as Phalaenopsis spp. (Tokuhara \& Mii 1993, Wang 2000). Regarding morphology and flowering period, our results obtained from greenhouse-grown $T$. stramineum plants coincide with development patterns previously reported for natural populations of the species (Jiménez 1990). 
Our protocol minimizes loss of genetic stability of the regenerated plants by inducing direct responses without the use of PGRs and limiting cultivation periods and cycles to a minimum (George 1993, Pandey et al. 2012). It could therefore also be applied to preservation programs, e.g., selected genotypes of threatened or genetically erode T. stramineum populations may be propagated following the methods described herein, thus ensuring normal plant development and avoiding somaclonal variation. A good example for the establishment of a cloning system for conservation purposes of small populations has been given by Mistretta (1994): Several individuals could be clonally propagated from a wild population of Cercocarpus traskiae Eastw., represented by only seven unique genotypes, and were successfully reintroduced to their native habitat.

\section{Acknowledgments}

The authors would like to thank the CIC-UMSNH and the Jardín Botánico IB-UNAM for financial support of this study.

\section{Literature cited}

Aktar S, Nasiruddin KM, Hossain K. 2008. Effects of Different Media and Organic Additives Interaction on In Vitro Regeneration of Dendrobium Orchid. Journal of Agriculture and Rural Development 6: 69-74. https:// doi.org/10.3329/jard.v6i1.1659

Arditti J, Ernst R. 1984. Physiology of germinating orchid seeds. In Arditti J. (ed.) Orchid Biology - Reviews and Perspectives III. pp. 177-222 Ithaca, London: Comstock Publishing, Cornell Univ. Press. ISBN 9780801410406

Arditti J. 2008. Micropropagation of orchids. Blackwell Publishing Ltd. 544 p. ISBN 978-1-444-30040-6

Bairu MW, Aremu AO, Van Staden J. 2011. Somaclonal variation in plants: causes and detection methods. Plant Growth Regulation 63: 147-173. https://doi.org/10.1007/ s10725-010-9554-x

Bairu MW, Fennell CW, van Staden J. 2006. The effect of plant growth regulators on somaclonal variation in Cavendish banana (Musa AAA cv'Zelig').Scientia Horticulturae 108: 347-351. https://doi.org/10.1016/ j.scienta.2006.01.039

Balachandran SM, Bhat SR, Chandel KPS. 1990. In vitro clonal multiplication of turmeric (Curcuma spp.) and ginger (Zingiber officinale Rosc.). Plant Cell Reports 8: 521-524. DOI: https://doi.org/10.1007/BF00820200

Bell RL, Srinivasan C, Lomberk D. 2009. Effect of nutrient media on axillary shoot proliferation and preconditioning for adventitious shoot regeneration of pears. In Vitro Cellular and Developmental Biology - Plant 45:
708-714. DOI: https://doi.org/10.1007/s11627-009-9196 $\underline{-8}$

Bhattacharyya P, Kumaria S, Diengdoh R, Tandon P. 2014. Genetic stability and phytochemical analysis of the in vitro regenerated plants of Dendrobium nobile Lindl., an endangered medicinal orchid. Meta gene 2: 489-504. https://doi.org/10.1016/j.mgene.2014.06.003

Bidabadi SS, Meon S, Wahab Z, Mahmood M. 2010. Study of genetic and phenotypic variability among somaclones induced by BAP and TDZ in micropropagated shoot tips of banana (Musa spp.) using RAPD markers. Journal of Agricultural Science 2: 49. DOI: https://doi.org/10.5539/ jas.v2n3p49

Biswas MK, Dutt M, Roy UK, Islam R, Hossain M. 2009. Development and evaluation of in vitro somaclonal variation in strawberry for improved horticultural traits. Scientia horticulturae 122: 409-416. https://doi.org/ 10.1016/j.scienta.2009.06.002

Cassells A, Curry R. 2001. Oxidative stress and physiological, epigenetic and genetic variability in plant tissue culture: implications for micropropagators and genetic engineers. Plant Cell, Tissue and Organ Culture 64: 145-157. https://doi.org/10.1023/A:1010692104861

Cha-um S, Ulziibat B, Kirdmanee C. 2010. Effects of Temperature and Relative Humidity During in'vitro'Acclimatization, on Physiological Changes and Growth Characters of'Phalaenopsis' Adapted to in 'vivo'. Australian Journal of Crop Science 4: 750.

CITES [Convention on International Trade in Endangered Species]. 2017. Convención sobre el comercio internacional de especies amenazadas de fauna y flora silvestres, Apéndices I, II y III. En vigor a partir del 4 de octubre de 2017. https://cites.org/sites/default/files/esp/ $\underline{\mathrm{app}} /$ 2017/S-Appendices-2017-10-04.pdf (accessed April 20, 2019).

Cui H, Murty HN, Moh SH, Yong-Yi C, Kee-Yoeup P. 2015. Establishment of Protocorm Suspension Cultures of Dendrobium candidum for the Production of Bioactive Compounds. Horticulture Environment and Biotechnology 56: 114-122. DOI: https://doi.org/10.10 07/s13580-015-0082-5

da Silva RL, Ferreira CF, da Silva Ledo CA, de Souza EH, da Silva PH, de Carvalho-Costa MAP, Souza FVD. 2016. Viability and genetic stability of pineapple germplasm after 10 years of in vitro conservation. Plant Cell, Tissue and Organ Culture 127: 123-133. DOI: https://doi.org/ $\underline{10.1007 / \mathrm{s} 11240-016-1035-0}$

Dávila-Figueroa CA, De La Rosa Carrillo ML, PérezMolphe-Balch E 2005. In vitro propagation of eight species or subspecies of Turbinicarpus (Cactaceae). In Vitro Cellular and Developmental Biology - Plant 41: 540-545. DOI: https://doi.org/10.1079/IVP2005668 
Ernst R. 1967. Effect of Select Organic Nutrient Additives on Growth in vitro of Phalaenopsis Seedlings. American Orchid Society Bulletin August: 694-704.

Espejo-Serna A, López-Ferrari AR, Jiménez-Machorro R, Sánchez-Saldaña L. 2005. Las orquídeas de los cafetales en México: una opción para el uso sostenible de ecosistemas tropicales. Revista de Biología Tropical 53: 73-84.

Evans DA. 1989. Somaclonal variation-genetic basis and breeding applications. Trends in Genetics, 5: 46-50. DOI: https://doi.org/10.1016/0168-9525(89)90021-8

Flores-Escobar G, Legaria-Solano JP, Gil-Vásquez I, Colinas-León MT. 2008. Propagación in vitro de Oncidium stramineum Lindl. una orquídea amenazada y endémica de México. Revista Chapingo Serie Horticultura 14: 347-353. DOI: http://dx.doi.org/ 10.5154/r.rchsh.2007.02.009

Gamborg OL, Miller RA, Ojima K. 1968. Nutrient requirements of suspension cultures of soybean root cells. Experimental Cell Research 50: 151-158. DOI: https://doi.org/10.1016/0014-4827(68)90403-5

Gentry SH. 1982. Agaves of Continental North America. Tucson; University of Arizona Press, 670 p. ISBN: 13: 978-0816523955

George EF. 1993. Plant propagation by tissue culture. Part 1: The technology (No. Ed. 2). Edington: Exegetics limited. ISBN 10: 095093254X; ISBN-13: 978-0950932545

Hosoki T, Sagawa Y. 1977. Clonal propagation of ginger (Zingiber officinale Roscoe) throught tissue culture. HortScience 12: 451-452.

Isabel N, Boivin R, Levasseur C, Charest PM, Bousquet J, Tremblay FM. 1996. Occurrence of somaclonal variation among somatic embryo-derived white spruces (Picea glauca, Pinaceae). American Journal of Botany 83: 1121-1130. https://doi.org/10.1002/j.1537-2197.1996.tb $\underline{13892 . \mathrm{x}}$

Jeon MW, Ali MB, Hahn EJ, Paek KY. 2005. Effects of photon flux density on the morphology, photosynthesis and growth of a CAM orchid, Doritaenopsis during postmicropropagation acclimatization. Plant Growth Regulation, 45: 139-147. DOI: https://doi.org/10.1007/ $\underline{\mathrm{s} 10725-005-0337-8}$

Jiménez R. 1990. Oncidium stramineum. (Lám. 79) In: Hágsater E, Salazar GA. (eds.). Icones Orchidacearum Fascicle 1: Orchids of Mexico. Part 1. pp.79. México: Asociación Mexicana de Orquideología, AC.

Johnson TR, Kane ME. 2007. Asymbiotic germination of ornamental Vanda: in vitro germination and development of three hybrids. Plant Cell, Tissue and Organ Culture 91: 251-261. DOI: https://doi.org/10.1007/s11240-007$\underline{9291-7}$
Khoddamzadeh AA, Sinniah UR, Kadir MA, Kadzimin SB, Mahmood M, Sreeramanan S. 2011. In vitro induction and proliferation of protocorm-like bodies (PLBs) from leaf segments of Phalaenopsis bellina (Rchb. f.) Christenson. Plant Growth Regulation 65: 381-387. https://doi.org/10.1007/s10725-011-9611-0

Knudson L. 1946. A new nutrient solution for the germination of Orchid Seeds. American Orchid Society Bulletin 15: 214-217.

Long B, Niemiera AX, Cheng ZY, Long CL. 2010. In vitro propagation of four threatened Paphiopedilum species (Orchidaceae). Plant Cell, Tissue and Organ Culture 101: 151-162. DOI: https://doi.org/10.1007/s11240-010$\underline{9672-1}$

Martin KP, Madassery J. 2006. Rapid in vitro propagation of Dendrobium hybrids through direct shoot formation from foliar explants, and protocorm-like bodies. Scientia Horticulturae 108: 95-99. DOI: https://doi.org/10.1016/ j.scienta.2005.10.006

Martínez-Palacios A, Cárdenas Navarro R, Hernández Ortega DB, Chávez-Ávila V. 2016. Micropropagation of Turbinicarpus valdezianus (Möeller) Glass \& Foster (Cactaceae) an Endemic Cactus in Northern Mexico. HortScience 51: 94-97. DOI: https://doi.org/10.21273/ HORTSCI.51.1.94

Martínez-Palacios A, Ortega-Larrocea P, Chávez V, Bye R. 2003. Somatic embryogenesis and organogenesis of Agave victoriae-reginae: Considerations for its conservation. Plant Cell, Tissue and Organ Culture 74: 135-142. https://doi.org/10.1023/A:1023933123131

Martínez-Palacios A. 1991. Propagación masiva in vitro y recuperación de poblaciones de orquídeas en peligro de extinción. MSc. Thesis, Universidad Nacional Autónoma de México.

Martins M, Sarmento D, Oliveira MM. 2004. Genetic stability of micropropagated almond plantlets, as assessed by RAPD and ISSR markers. Plant Cell Reports 23: 492-496. https://doi.org/10.1007/s00299004-0870-3

Mehrotra S, Goel MK, Kukreja AK, Mishra BN. 2007. Efficiency of liquid culture systems over conventional micropropagation: A progress towards commercialization. African Journal of Biotechnology $\mathbf{6}$ : 1484-492.

Miguel CO, Marum L. 2011. An epigenetic view of plant cells cultured in vitro: somaclonal variation and beyond. Journal of Experimental Botany 62: 3713-3725. DOI: https://doi.org/10.1093/jxb/err155

Mistretta O. 1994. Genetics of species reintroductions: Applications of genetic analysis. Biodiversity and Conservation 3: 184-190. https://doi.org/10.1007/BF022 $\underline{91888}$ 
Morel GM. 1974. Clonal Multiplication of Orchids. In: Withner CL. (ed.). The Orchids, Scientific Studies, pp. 169-222. New York: John Wiley \& Sons. ISBN: 0898748097,9780898748093

Niknejad A, Kadir MA, Kadzimin SB. 2011. In vitro plant regeneration from protocorms-like bodies (PLBs) and callus of Phalaenopsis gigantea (Epidendroideae: Orchidaceae). African Journal of Biotechnology 10: 11808-11816.

Nobel PS. 1985. Environmental Responses of Agaves a case study with Agave deserti . In: Cruz C, Del Castillo L, Robert M, Ondarza RN. (eds.), Biología y Aprovechamiento Integral del Henequén y otros Agaves. pp. 55-66. México: Centro de Investigación Científica de Yucatán, AC.

Nobel PS. 1992. Annual variations in flowering percentage, seedling establishment and ramet production flora desert perennial. The International Journal of Plant Sciences 153: 102-107. DOI: https://doi.org/10.1086/297011

Pandey RN, Singh SP, Rastogi J, Sharma ML, Singh RK. 2012. Early assessment of genetic fidelity in sugarcane ('Saccharum officinarum') plantlets regenerated through direct organogenesis with RAPD and SSR markers. Australian Journal of Crop Science 6: 618.

Park S, Murthy HN, Paek K. 2002. Rapid propagation of Phalaenopsis from floral stalk-derived leaves. In Vitro Cellular and Developmental Biology - Plant 38: 168-172. DOI: https://doi.org/10.1079/IVP2001274

Radić S, Prolić M, Pavlica M, Pevalek-Kozlina B. 2005. Cytogenetic stability of Centaurea ragusina long-term culture. Plant Cell, Tissue and Organ Culture 82: 343-348. DOI: https://doi.org/10.1007/s11240-005-2388y

Rai MK, Phulwaria M, Gupta AK, Shekhawat NS, Jaiswal U. 2012. Genetic homogeneity of guava plants derived from somatic embryogenesis using SSR and ISSR markers. Plant Cell, Tissue and Organ Culture 111: 259-264. DOI: https://doi.org/10.1007/s11240-012-01 90-1

Rani V, Raina SN. 2000. Genetic fidelity of organized meristem-derived micropropagated plants: a critical reappraisal. In Vitro Cellular \& Developmental BiologyPlant 36: 319-330. DOI: http://dx.doi.org/10.1007/ s11627-000-0059-6

Rani V, Parida A, Raina SN. 1995. Random amplified polymorphic DNA (RAPD) markers for genetic analysis in micropropagated plants of Populus deltoides Marsh. Plant Cell Reports. 14: 459-462. DOI: https://doi.org/ 10.1007/BF00234055

Remolina R. 2015. Trichocentrum stramineum. http:// amo.com.mx/galerias/Mexicanas/slides/Trichocentrum \%20stramineum.html (accessed October 1, 2019)
Rodríguez M, Chacón M, Carrillo R. 2014. Efecto de la concentración y de los componentes del medio de cultivo MS sobre la germinación in vitro de Ugni molinae. Bosque 35: 119-22. $\quad$ http://dx.doi.org/10.4067/ $\underline{\mathrm{S} 0717-92002014000100012}$

Rout GR, Palai SK, Samantaray S, Das P. 2001. Effect of growth regulator and culture conditions on shoot multiplication and rhizome formation in ginger (Zingiber officinale Rosc.) in vitro. In Vitro Cellular \& Developmental Biology-Plant 37: 814-819. https:// doi.org/10.1007/s11627-001-0135-6

Rubluo A, Chávez V, Martínez A, Martínez-Vázquez O. 1993. Strategies for the recovery of endangered orchids and cacti through in vitro culture. Biological Conservation 63: 163-169. https://doi.org/ $\underline{\text { 10.1016/0006-3207(93)90505-U }}$

SEMARNAT [Secretaría del Medio Ambiente y Recursos Naturales]. 2010. Norma Oficial Mexicana NOM-059ECOL-2010. Protección ambiental. Especies nativas de México de flora y fauna silvestres. Categorías de riesgo y especificaciones para su inclusión, exclusión o cambio. Lista de especies en riesgo. Diario Oficial de la Federación, 30 de diciembre de 2010.

Singh G, Sandhu SK, Meeta M, Singh K, Gill R, Gosal SS. 2008. In vitro induction and characterization of somaclonal variation for red rot and other agronomic traits in sugarcane. Euphytica 160: 35-47. DOI: https:// doi.org/10.1007/s10681-007-9531-2

Soto-Arenas MA, Hágsater E, Jiménez-Machorro R, Salazar-Chávez G, Solano-Gómez R, Flores-González R, Ruiz Contreras I. 2007a. Las orquídeas de México. DVD. México City: Catálogo digital. Instituto Chinoín, AC.

Soto-Arenas MA, Solano-Gómez R, Hágsater E. 2007b. Risk of extinction and patterns of diversity loss in Mexican orchids. Lankesteriana 7: 114-121. DOI: https://doi.org/10.15517/lank.v7i1-2.18449

SAS [Statistical Analysis System Institute]. 1999. Statistical Analysis System SAS/STAT ${ }^{\circledR}$ User's Guide, V.8. Cary, NC USA: SAS Institute Inc.

Tokuhara K, Mii M. 1993. Micropropagation of Phalaenopsis and Doritaenopsis by culturing shoot tips of flower stalk buds. Plant Cell Reports 13: 7-11. DOI: https://doi.org/10.1007/BF00232306

Torp AM, Andersen SB. 2009. Albinism in microspore culture. In: Touraev A, Forster B, Jain S. Advances in Haploid Production in Higher Plants. pp. 155-160. Dordrecht: Springer. https://doi.org/10.1007/978-1-40208854-4_12. ISBN 978-1-4020-8854-4

Valdiviezo AC, Castillo J. 2011. El bambú en México. Arquitectura y urbanismo 6: 223-243. 
Villaseñor JL. 2016. Checklist of the native vascular plants of Mexico. Revista Mexicana de Biodiversidad 87: 559-02. DOI: http://dx.doi.org/10.1016/j.rmb.2016.06. $\underline{017}$

Vovides AP, Luna V, Medina G. 1997. Relación de algunas plantas y hongos mexicanos raros, amenazados o en peligro de extinción y sugerencias para su conservación. Acta Botánica Mexicana 39: 1-42. DOI: https://doi.org/ 10.21829/abm39.1997.774

Vujović T, Ružić Đ, Cerović R, Momirović GŠ. 2010. Adventitious regeneration in blackberry (Rubus fruticosus L.) and assessment of genetic stability in regenerants. Plant Growth Regulation 61: 265-275. DOI: https://doi.org/10.1007/s10725-010-9474-9

Wang Y. 2000. Impact of a high phosporus fertilizer and timing of termination of fertilization on flowering of a hybrid moth orchid. HortScience. 35: 60-62. DOI: https://doi.org/10.21273/HORTSCI.35.1.60

\footnotetext{
Associate editor: Martín Mata Rosas

Author Contributions: SRO: Wrote the draft and, based on the comments of all authors, the final version of the manuscript. LMRG: Propagated the in vitro cultures derived from apical bud explants. MEPS: Established the greenhouse plants and supervised their development. VMCÁ: Propagated the in vitro cultures derived from stem apex explants. JGMÁ: Conducted the collection and conservation of seeds. NMSV: Took the photographs, created the diagrams, and conducted the statistical analysis. AMP: Micropropagated the in vitro cultures and performed the greenhouse experiments.
}

Wen XP, Deng XX. 2005. Micropropagation of chestnut rose (Rosa roxburghii Tratt) and assessment of genetic stability in in vitro plants using RAPD and AFLP markers. The Journal of Horticultural Science and Biotechnology 80: 54-60. DOI: https://doi.org/10.1080/ $\underline{14620316.2005 .11511891}$

Williams EG, Maheswaran G. 1986. Somatic embryogenesis: factors influencing coordinated behaviour of cells as an embryogenic group. Annals of Botany 57: 443-462. DOI: https://doi.org/10.1093/ oxfordjournals.aob.a087127

Zhao P, Wu F, Feng FS, Wang WJ. 2008. Protocorm-like body (PLB) formation and plant regeneration from the callus culture of Dendrobium candidum Wall ex Lindl. In Vitro Cellular and Developmental Biology-Plant 44: 178. DOI: https://doi.org/10.1007/s11627-007-9101-2 